\title{
Pemberdayaan Kepada Siswa di SMPN 11 Samarinda tentang Edukasi Penanganan Dismenorea Primer
}

\author{
Rr Nindya Mayangsari ${ }^{*}$, Yessica Eka Puri², Mu'nisatul Fauziyah ${ }^{3}$, Annisa $^{4}$ \\ 1*. STIKES Mutiara Mahakam Samarinda, Jl Ery Suparjan No 49 A, Kota Samarinda, Indonesia 75119 \\ 2. STIKES Mutiara Mahakam Samarinda, J1 Ery Suparjan No 49 A, Kota Samarinda, Indonesia 75119 \\ 3. STIKES Mutiara Mahakam Samarinda, Jl Ery Suparjan No 49 A, Kota Samarinda, Indonesia 75119 \\ 4. STIKES Mutiara Mahakam Samarinda, Jl Ery Suparjan No 49 A, Kota Samarinda, Indonesia 75119 \\ *email : nindyamayangsari@gmail.com
}

\begin{abstract}
Abstrak
Masa remaja adalah suatu fase perkembangan yang dinamis dalam kehidupan seseorang. Salah satu tanda keremajaan secara biologi yaitu mulainya remaja mengalami menstruasi yang dimulai antara usia 10 sampai 19 tahun. Menstruasi merupakan hal yang bersifat fisiologis yang terjadi pada setiap perempuan. Namun pada kenyataannya banyak perempuan yang mengalami masalah menstruasi, diantaranya nyeri haid/dismenorea. Telah dilakukan Program Kemitraan Masyarakat (PKM) yang melibatkan siswa di SMP N 13 Samarinda. Secara umu tujuan dari kegiatan ini adalah untuk meningkatkan pengetahuan remaja tentang dismenorea dan penanganannya. Target khusus melalui kegiatan ini diharapkan siswa mampu menerapkan pengetahuan yang telah diberikan melalui kegiatan PKM ini, yakni melakukan penanganna terhadap dismenorea pada diri sendiri, saudara perempuan dan teman perempuannya. Metode yang digunakan dalam sasaran siswa di SMP N 13 Samarinda melalui pre test dan post test. Data hasil kegiatan PKM ini, kemudian dikategorikan menjadi 3 respon pemahaman yakni : baik (80-100), cukup (70-55) dan kurang $(<55)$. Hasil yang didapatkan dari kegiatan ini menunjukkan dari 36 siswa dapat dikategorikan nilai pre test 8 siswa (baik), 8 siswa (cukup) dan 20 siswa (kurang), sedangkan hasil post test terjadi peningkatan yaitu 28 siswa (baik), 6 siswa (cukup), dan 2 siswa (kurang). Jadi dapat disimpulkan terjadi peningkatan pemahaman siswa setelah mengikuti kegiatan ini dalam memberikan penanganan yang tepat baik secara farmakologis atau non farmakologis.
\end{abstract}

Kata Kunci : Dismenorea, Farmakologis, Remaja, Non Farmakologis

\section{Pendahuluan}

Adolescent (remaja) adalah suatu masa transisi dari anak-anak menjadi dewasa. Menurut World Health Organization (WHO), remaja adalah penduduk dalam rentang usia 10-19 tahun. Masa remaja merupakan masa perkembangan pada diri remaja yang sangat penting, diawali dengan matangnya organ-organ fisik (seksual) sehingga nantinya mampu bereproduksi. Pada masa remaja terdapat perubahan-perubahan yang terjadi seperti perubahan hormonal, fisik, psikologis maupun sosial, dimana kondisi tersebut dinamakan dengan masa pubertas. Salah satu tanda pubertas pada remaja putri yaitu terjadinya menstruasi (Batubara, 2012). Pada saat menstruasi, masalah yang dialami oleh hampir sebagian besar wanita adalah rasa tidak nyaman atau rasa nyeri yang hebat. Hal ini biasa disebut dengan nyeri haid (dismenorea). Menurut data WHO di Indonesia angka kejadian dismenorea sebanyak 55\% dikalangan usia produktif, dimana 15\% diantaranya mengeluhkan aktivitas menjadi terbatas akibat dismenorea (Fahmi, 2014).

Nyeri haid (dismenoreaa) adalah gangguan fisik yang sangat menonjol pada wanita yang sedang mengalami menstruasi berupa gangguan nyeri/kram pada perut (Lestari, 2013). Nyeri haid (dismenorea) memiliki dampak yang cukup besar bagi remaja putri karena menyebabkan terganggunya aktivitas sehari-hari. Remaja putri yang mengalami nyeri haid (dismenorea) pada saat menstruasi akan merasa terbatas dalam melakukan aktivitas khususnya aktivitas belajar di sekolah. Menurut Rohmat (2013) aktivitas belajar gadalah keterlibatan seseorang dalam bentuk sikap, pikiran dan perhatian dalam kegiatan belajar sebagai penunjang keberhasilan proses belajar mengajar sehingga di peroleh manfaat dari kegiatan tersebut. Remaja putri yang sedang mengalami nyeri haid (dismenorea) sekaligus mengikuti kegiatan pembelajaran, dapat menyebabkan aktivitas pembelajaran menjadi terganggu, tidak bersemangat, konsentrasi menjadi menurun bahkan sulit berkonsentrasi sehingga materi yang disampaikan selama pembelajaran tidak dapat diterima dengan baik bahkan sampai ada yang tidak masuk sekolah.

Penelitian terdahulu oleh Saguni (2013) menunjukkan bahwa siswi yang mengalami gangguan dalam aktivitas belajar diakibatkan karena nyeri haid yang dirasakan dalam proses pembelajaran. Hal ini menyebabkan siswi sulit untuk berkonsentrasi karena ketidaknyamanan yang dirasakan ketika mengalami nyeri haid (dismenorea) pada saat jam pelajaran berlangsung juga ada yang sampai meminta izin untuk pulang dan terkadang ada yang meminta izin untuk diberikan dispensasi beristirahat di ruangan UKS. Penelitian lain oleh Handayani (2011) menjelaskan bahwa dismenorea merupakan salah satu penyebab utama absen sekolah pada remaja putri untuk beberapa jam atau beberapa 
hari. Hal tersebut dihubungkan pada pengaruh negatif terhadap aktivitas sosial pada kebanyakan remaja putri. Remaja putri yang mengalami dismenorea pada saat menstruasi mempunyai lebih banyak libur sekolah atau absen dan prestasinya kurang begitu baik di sekolah dibandingkan mereka yang tidak mengalami dismenorea.

SMP N 13 Samarinda adalah salah satu SMP di wilayah Samarinda yang memiliki jarak $+5 \mathrm{~km}$ dari STIKES Mutiara Mahakam Samarinda. Dari data survei pendahuluan yang dilakukan oleh peneliti didapatkan bahwa 8 dari 10 siswi pernah mengalami nyeri haid (dismenorea) saat sedang mengalami menstruasi, merasakan sakit pada bagian perut dan menjalar kebawah bagian panggul, merasakan sakit pada bagian perut dan menjalar kebawah bagian panggul, merasa kurang nyaman saat beraktivitas dan tidak bersemangat saat mengikuti pembelajaran di sekolah. Selain itu, anggapan masih tabu dan asing diantara siswa terkait dismenorea sehingga mengakibatkan sedikitnya ilmu yang dimiliki oleh siswa terkait tentang dismenorea primer dan penanganannya. Sehingga dianggap perlu dilakukan edukasi penanganan primer dismenorea di sekolah ini. Melihat begitu banyaknya kejadian dismenorea atau nyeri haid maka dilakukan pemberian edukasi dan penanganan primer dismenorea pada siswi SMP N 13 Samarinda.

\section{Metode}

a. Pengenalan dan Persiapan

Kegiatan PKM ini dilaksanakan dalam bentuk ceramah, tanya jawab dan diskusi yang diberikan pada siswa di SMP N 13 Samarinda yang kemudian dilanjutkan dengan edukasi tentang penanganan dismenorea primer dan memperkenalkan terapi farmakologi dan non farmakologi. Dalam lokasi kegiatan PKM diawali dengan melakukan survei awal ke SMP N 13 Samarinda pada tanggal 09 Oktober 2018. Dalam tahapan ini, dapat dilakukan identifikasi masalah terkait pengetahuan remaja secara umum melalui wawancara dengan remaja terkait penyakit umum yang paling sering dialami oleh remaja putri adalah dismenorea yang paling sering dialami oleh remaja putri dan seberapa besar tindakan yang remaja mampu lakukan untuk menanggapi masalah tersebut.

Pengurusan izin kegiatan PKM dilakukan dengan terlebih dahulu mengantarkan surat pengantar pelaksanaan kegiatan PKM dari institusi kepada Kepala Sekolah SMP N 13 Samarinda. Pengurusan izin ini dilakukan 1 minggu setelah survey dilaksanakan. Selanjutnya dilakukan pembicaraan bersama dengan kepala sekolah terkait metode dan rangkaian kegiatan PKM yang akan dilaksanakan. Dari diskusi tersebut, kemudian diperoleh kesepakatan bersama terkait pengaturan rencana kegiatan dan jadwal pelaksanaan kegiatan sehingga komitmen untuk mengikuti dan berpartisipasi aktif lebih tinggi demi kelancaran edukasi ini.

b. Mekanisme Pelaksanaan Ppengabdian Masyarakat

Pelaksanaan kegiatan PKM dilaksanakan tanggal 09 Oktober 2018 dari pukul 13.00 - 16.00 WITA. Proses penyelenggaraan edukasi ini dilakukan di SMP N 13 Samarinda dimana kegiatan ini diawali dengan pengenalan dan penggalian pengetahuan peserta edukasi mengenai observasi dismenorea. Peserta kemudian diberikan waktu untuk mengisi kuesioner pretest yang kemudian dilanjutkan dengan ceramah dan diskusi yang berjalan lancar dalam pelaksanaannya, serta pemberian post test di akhir sebagai penilaian. Pelaksanaan kegiatan ini diawali dengan pemberian materi oleh pemateri tentang dismenorea primer dan penanganannya dibantu dengan media pembelajaran yang digunakan dalam pelaksanaan edukasi tentang penanganan dismenorea primer yang diberikan. Hasil pre-test dan post test kemudian dikategorikan menjadi 3 respon pemahaman :

1. Nilai 80-100 dianggap pemahaman peserta baik

2. Nilai 70-55 dianggap pemahaman peserta cukup

3. Nilai <55 dianggap pemahaman peserta kurang

\section{Hasil}

a. Karakteristik Peserta

Peserta sasaran pada kegiatan PKM ini adalah siswa kelas VIII di SMP N 13 Samarinda dengan karakteristik umur 15-17 tahun, baik laki-laki (usia 15 tahun sebanyak 5 siswa, usia 16 tahun sebanyak 5 siswa dan usia 17 tahun sebanyak 6 siswa) maupun perempuan ( usia 15 tahun sebanyak 5 siswi, usia 16 tahun sebanyak 10 siswi dan usia 17 tahun sebanyak 5 siswi) yang mampu membaca, sehat dan membutuhkan informasi terkait dismenorea dan penanganan primernya. Jumlah siswa pada kegiatan PKM ini adalah 36 siswa yakni 16 laki-laki dan 20 perempuan. Pemberian edukasi terkait dismenorea tidak hanya diberikan kepada siswi melainkan juga kepada siswa karena bias memberikan informasi terkait penanganan dismenorea primer ini ke teman, adik, kakak perempuannya atau ibunya.

b. Respon Peserta

Respon peserta sangat baik terbukti dengan antusiasnya dalam memberikan pertanyaan dan berbagi pengalaman. Dalam pelaksanaan pemberian materi, penambahan pengetahuan tidak semuanya mudah diserap dalam waktu singkat, sehingga pentingnya pemberian pengetahuan lebih lanjut dengan memberikan edukasi penanganan dismenorea primer. Nilai pre test dan post test dapat dilihat pada tabel 1 dan 2 . 
Tabel 1. Hasil pre-test promosi kesehatan

\begin{tabular}{|c|c|c|}
\hline Kategori Nilai & $\mathrm{n}$ & $\%$ \\
\hline Baik & 8 & $22,2 \%$ \\
Cukup & 8 & $22,2 \%$ \\
Kurang & 20 & $55,6 \%$ \\
\hline Total & 36 & $100 \%$ \\
\hline
\end{tabular}

Tabel 1. Menunjukkan hasil respon dari 36 siswa yang dikategorikan nilai pre test 8 siswa (baik), 8 siswa (cukup) dan 20 siswa (kurang).

Tabel 2. Hasil post test promosi kesehatan

\begin{tabular}{|c|c|c|}
\hline Kategori Nilai & $\mathrm{n}$ & $\%$ \\
\hline Baik & 28 & $77,8 \%$ \\
Cukup & 6 & $16,7 \%$ \\
Kurang & 2 & $5,5 \%$ \\
\hline Total & 36 & $100 \%$ \\
\hline
\end{tabular}

Tabel 2. Menunjukkan hasil respon dari 36 siswa yang dikategorikan nilai post test 28 siswa (baik), 6 siswa (cukup), dan 2 siswa (kurang).

Untuk kegiatan edukasi dapat terlihat siswa yang mengikuti mampu menjelaskan kembali cara penanganan secara farmakologi maupun non-farmakologi ketika saat edukasi penanganan dismenorea primer. Capaian keberhasilan diukur dengan membagi peserta kelompok menjadi 4.

c. Luaran kegiatan

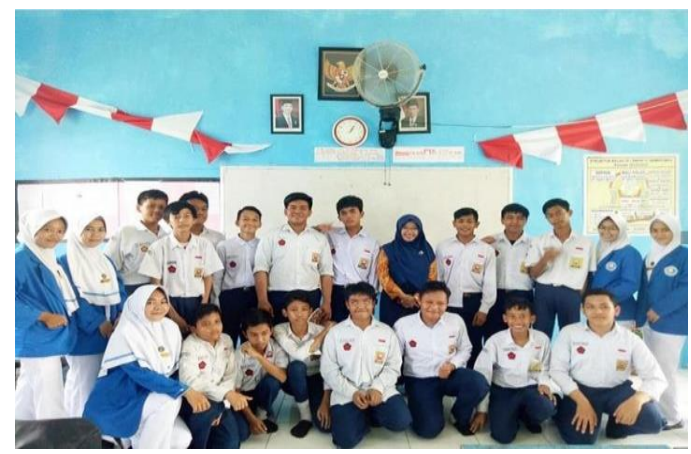

Gambar 1. Dokumentasi kegiatan pemberian promosi kesehatan

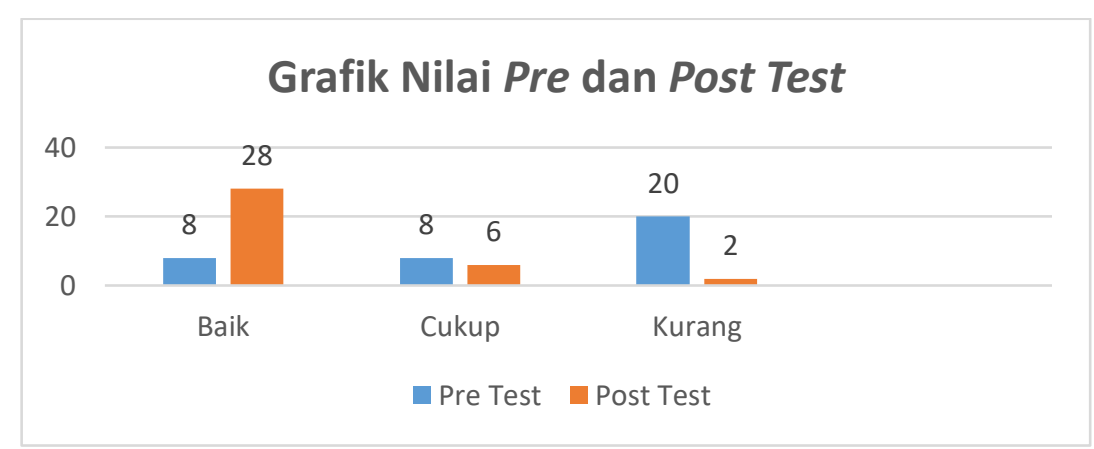

Gambar 2 Grafik Nilai pre test dan post test promosi kesehatan

Pada grafik nilai pre test dan post test diatas, dapatkan hasil dengan nilai baik dari 8 siswa menjadi 28 siswa, nilai cukup dari 8 siswa menjadi 6 siswa dan nilai kurang dari 20 siswa menjadi 2 siswa. Dari data tersebut didapatkan hasil bahwa terjadi peningkatan pengetahuan setelah diberikan edukasi penanganan dismenorea primer.

Hasil pengabdian kepada masyarakat menunjukkan bahwa ada peningkatan pengetahuan dalam penanganan dismenorea setelah diberikan edukasi dan penangan dismenorea yang dibuktikan dengan adanya perbedaan nilai pre test dan post test program edukasi dan penangan dismenorea dalam penguatan ilmu kesehatan. Berarti edukasi ini dapat meningkatkan pengetahuan siswa dan mengerti dalam penanganan dismenorea sehingga dapat menambah ilmu kesehatan reproduksi terkait dismenorea dan penanganannya. Tujuan dari program ini agar siswa dan siswi 
dapat memberikan penanganan dismenorea dan mengerti akan kesehatan reproduksi baik pada diri sendiri maupun saudara perempuannya dan teman perempuan disekitarnya.

Menurut Medicastore (2004), wanita yang mempunyai resiko menderita dismenorea primer adalah: 1)Konsumsi Alkohol, Alkohol merupakan racun bagi tubuh. Hati bertanggungjawab terhadap penghancur estrogen untuk disekresi tubuh. Adanya alkohol dalam tubuh secara terus menerus dapat mengganggu fungsi

hati sehingga estrogen tidak dapat disekresi tubuh sehingga estrogen yang menumpuk dalam tubuh dapat merusak pelvis. 2)Perokok, Merokok dapat meningkatkan lamanya mensruasi dan meningkatkan lamanya dismenorea. 3)Tidak pernah berolah raga, Kejadian dismenorea akan meningkat dengan kurangnya aktifitas selam menstruasi dan kurangnya olah raga, hal ini dapat menyebabkan sirkulasi darah dan oksigen menurun. Dampak pada uterus adalah aliran darah dan sirkulasi oksigen pun berkurang dan menyebabkan nyeri. 4)Stres, Stres menimbulkan penekanan sensasi saraf-saraf pinggul dan otot-otot punggung bawah sehingga menyebabkan dismenorea.

Upaya farmakologis yang dapat dilakukan dengan memberikan obat analgesik sebagai penghilang rasa sakit. Menurut Bare \& Smeltzer (2002 dalam Hermawan, 2012), penanganan nyeri yang dialami oleh individu dapat melalui intervensi farmakologis, dilakukan kolaborasi dengan dokter atau pemberi perawatan utama lainnya pada pasien. Obat-obatan ini dapat menurunkan nyeri dan menghambat produksi prostaglandin dari jaringan-jaringan yang mengalami trauma dan inflamasi yang menghambat reseptor nyeri untuk menjadi sensitive terhadap stimulus menyakitkan sebelumnya, contoh obat anti inflamasi nonsteroid adalah aspirin, ibuprofen.

Menurut Bare \& Smeltzer (2002 dalam Hermawan 2012) penanganan nyeri secara nonfarmakologis terdiri dari: 1) Stimulasi dan Masase kutaneus, Masase adalah stimulus kutaneus tubuh secara umum, sering dipusatkan pada punggung dan bahu. Masase dapat membuat pasien lebih nyaman karena masase membuat relaksasi otot. 2) Terapi es dan panas, Terapi es dapat menurunkan prostsglandin yang memperkuat sensitifitas reseptor nyeri dan subkutan lain pada tempat cedera dengan menghambat proses inflamasi. Terapi panas mempunyai keuntungan meningkatkan aliran darah ke suatu area dan kemungkinan dapat turut menurunkan nyeri dengan memprcepat penyembuhan. 3) Transecutaneus Elektrikal Nerve Stimulaton ( TENS) 4) Distraksi, Distraksi adalah pengalihan perhatian dari hal yang menyebabkan nyeri, contoh: menyanyi, brdoa, menceritakan gambar atau foto denaga kertas, mendengar musik dan bermain satu permainan. 5) Relaksasi, Relaksasi merupakan teknik pengendoran atau pelepasan ketegangan. Teknik relaksasi yang sederhana terdiri atas nafas abdomen dengan frekuensi lambat, berirama (teknik relaksasi nafas dalam. Contoh: bernafas dalam-dalam dan pelan. 6) Imajinasi.

Melalui kegiatan terprogram dalam pemberian edukasi penanganan dismenorea primer maka dapat menurunkan rasa nyeri dismenorea. Oleh karena itu, penggalakan upaya terprogam dalam pemberian edukasi dan penanganan dismenorea primer sangat disarankan untuk dilaksanakan berkesinambungan.

\section{Kesimpulan}

Melihat dari masalah tersebut dengan adanya program edukasi dan penanganan dismenorea primer di SMP N 13 Samarinda yang berjalan dengan lancar dan sesuai dengan rencana kegiatan yang telah disusun, serta pengetahuan remaja tentang dismenorea dan penanganannya juga meningkat. Kegiatan ini mendapatkan sambutan yang sangat baik terlihat dari antusias siswa dan keaktifan dalam menerima materi yang telah disampaikan. Selain itu, capaian juga terlihat dari peningkatan nilai post test dan kemampuan siswa melakukan praktek penanganan dismenorea saat edukasi dilakukan. Pada grafik nilai pre test dan post test pemberian edukasi penanganan dismenorea primer, dapatkan hasil dengan nilai baik dari 8 siswa menjadi 28 siswa, nilai cukup dari 8 siswa menjadi 6 siswa dan nilai kurang dari 20 siswa menjadi 2 siswa. Dari data tersebut didapatkan hasil bahwa terjadi peningkatan pengetahuan setelah diberikan edukasi penanganan dismenorea primer.

\section{Saran}

Berdasarkan evaluasi yang telah dilaksanakan dapat direkomendasikan untuk melakukan kegiatan lanjutan dari tenaga kesehatan untuk memberikan health education terkait penanganan dismenorea. Serta diharapkan keaktifan pihak yang terkait yakni para orang tua juga perlu mencari informasi dan tidak menganggap dismenorea sebagai hal yang biasa. Mereka dapat mengajak putri mereka mengunjungi dokter atau terapis untuk mendapatkan terapi baik secara farmakologis atau non farmakologis. Selain itu juga perlu adanya pihak dari Puskesmas terdekat agar lebih memperhatikan kegiatan yang ada dan membantu terkait kesehatan reproduksi bagi siswa dan siswi sehingga siswa menjadi lebih menjaga, merawat dan mengetahui kesehatan reproduksi masing-masing.

\section{Daftar Pustaka}

Batubara, Jose RL. (2012). Adolescent Development (Perkembangan Remaja). (Online). (http://saripediatri.idai.or.id/pdfile/12-15.pdf), diakses 18 Februari 2019

Fahmi. (2014). Hubungan Antara Dismenorea dengan Usia Menarche dan Indeks Massa Tubuh. (Online). (http://repository.usu.ac.id/bitstream/123456789/41010/4/Chapter\%20II.pdf), diakses 11 Januari 2019 
Handayani. Trisna Yuni dan Dewi Rokhanawati. (2011). Hubungan Dismenoreaa Terhadap Aktivitas Belajar Siswi SMA Muhammadiyah 5 Yogyakarta Tahun 2011. Jurnal Kebidanan, (Online). (http://opac.unisayogya.ac.id/1580/), diakses 06 Januari 2019

Hermawan. 2012. Dismenorea (nyeri saat haid). Jakarta : Erlangga

Lestari, Ni Made Sri Dewi. (2013). Pengaruh Dismenorea pada Remaja, Jurnal Ilmu Kesehatan, (Online). (http://ejournal.undiksha.ac.id/index.php/semnasmipa/article/view/2725), diakses 15 Januari 2019

Medicastore. 2004. Penatalaksanaan Fisioterapi Pada Nyeri Haid. Tersedia di http://medicastorenewsid 1059624784. Diakses tanggal 2 Januari 2019.

Rohmat. (2013). Aktivitas Belajar, Hasil Belajar, Metode Diskusi Dan Pendidikan Kewarganegaraan. (Online). (http://eprints.walisongo.ac.id/984/3/083911045_Bab2.pdf), diakses 23 Januari 2019

Saguni, Fersta Cicilia Apriliani, dkk. (2013). Hubungan Dismenorea dengan Aktivitas Belajar Remaja Putri di SMA Kristen I Tomohon. Jurnal Keperawatan, (Online), 1 (1), (https://ejournal.unsrat.ac.id/index.php/jkp/article/view/2182), diakses 06 Januari 2019 